\title{
Nutritional effects of field bean (Vicia faba L.) proteinase inhibitors fed to rats
}

\author{
By BENE W. ABBEY, R. J. NEALE AND G. NORTON \\ Department of Applied Biochemistry and Nutrition, \\ University of Nottingham School of Agriculture, \\ Sutton Bonington, Loughborough LEI 2 SRD
}

(Received 12 April 1978 - Accepted 30 May 1978)

I. Weanling rats were fed on purified-casein diets containing active and inactive (autoclaved) field bean (Vicia faba L.) proteinase inhibitors (PI) at levels of $1 \cdot 25,2.5,5.0$ and $10 \mathrm{~g} / \mathrm{kg}$. Diets containing raw- and autoclaved-field-bean meal (FBM) were also given. The body-weight gain, protein efficiency ratio (PER); i.e. the ratio of the live weight gain in $\mathrm{g} / \mathrm{g}$ of protein consumed and apparent nitrogen digestibility were determined 7,14 and $21 \mathrm{~d}$ after the start of the trial.

2. Significant growth depression $(P<0.00 \mathrm{I})$ was observed in rats given diets containing $2.5 \mathrm{~g} / \mathrm{kg} \mathrm{PI}$ $(27-35 \%)$. In rats fed on raw FBM growth depression was severe after $7 \mathrm{~d}(57 \%)$.

3. Food intake was depressed at PI inclusion levels of $5 \mathrm{~g} / \mathrm{kg}$ and higher between $\mathrm{I} 4$ and $2 \mathrm{I}$ d.

4. PER was depressed significantly $(33-44 \%)$ in rats given diets containing the active PI at all levels after $7 \mathrm{~d}$. The protein utilization of all casein diets was higher than that of the FBM diets.

5. Apparent $\mathrm{N}$ digestibility was depressed in rats fed on diets containing $10 \mathrm{~g} / \mathrm{kg}$ PI by 9 and $7 \%$ at 14 and 21 d respectively. The $\mathrm{N}$ digestibility of both raw and heated FBM was similar at approximately $84 \%$.

6. It was concluded that the PI are not the main factors responsible for the growth depression observed when raw FBM is fed to rats.

The growth depression caused by raw legume seeds in the diets of animals has often been attributed to the presence of heat-labile factors such as proteinase inhibitors (PI) (Osborne \& Mendel, I917; Gertler et al. I967), haemagglutinins (Liener, 195I) and saponins (Ishaaya \& Birk, 1965). However, it is not known to what extent each component is concerned in the growth depression. Rackis (I965) estimated that the PI were responsible for approximately $30-50 \%$ of the growth depression and practically all the pancreatic hypertrophy when raw soya-bean meal was fed to rats. Recently, Kakade et al. (I973) showed that PI were responsible for $40 \%$ of the growth depression observed when rats were fed on diets containing raw soya-bean meal. Raw FBM has also been found to depress growth of both rats and chicks (Sohonie et al. I958; Nitsan, 197I; Wilson \& McNab, I972; Marquardt \& Campbell, 1973; Kadirvel \& Clandinin, 1974) and PI have been implicated in this response.

The work reported here was initiated to determine the nutritional and physiological significance of PI by means of incorporating the partially purified FBM inhibitors into diet devoid of other legume proteins. For comparison the nutritive value of FBM was also investigated to ascertain the importance if any, of PI and other anti-nutritional factors.

\section{MATERIALS AND METHODS}

Rats

Male weanling Wistar strain rats bred at the University of Nottingham School of Agriculture were used. The rats were distributed randomly, two per cage, in raised wire mesh bottom cages. A large metal tray covered with Whatman No. I filter paper which was changed daily was used to collect faeces and spilt food. Food pots were weighed daily and replenished. 
Account was taken of spilt food in measuring food intake values. Contamination of spilt food with urine and faeces occurred occasionally but in most instances the faeces could be separated satisfactorily by sieving. Faeces were collected daily throughout the experimental period and after removing contaminating hairs and feed were lyophilized and ground to a fine powder.

\section{Preparation of $P I$}

PI were extracted from field beans (Vicia faba L.) and partially purified according to the procedure of Warsy et al. (1974). Initially it was intended to use the highly purified PI from FBM but the low yields of these proteins of high specific activity precluded this approach. As a compromise PI were extracted from field beans (Vicia faba L.) and partially purified according to the procedure of Warsy et al. (I974). I kg of FBM was extracted twice with five volumes of $2.5 \%$ trichloroacetic acid (TCA) for $24 \mathrm{~h}$ at $20^{\circ}$ with continuous stirring. After centrifugation at $\mathrm{I} 5000 \mathrm{~g}$ for $30 \mathrm{~min}$ the combined supernatants (pH $\mathrm{I} \cdot 9$ ) were adjusted to $\mathrm{pH} 4.5$ with $2 \mathrm{M}-\mathrm{NaOH}$. After standing for $\mathrm{I} \mathrm{h}$ at $20^{\circ} \mathrm{C}$, the suspension was clarified by centrifugation at $15000 \mathrm{~g}$ for $30 \mathrm{~min}$. The supernatant was fractionated at 300 , 400,500 and $1000 \mathrm{~g}$ ammonium sulphate $/ 1$ and the precipitates in each case were collected by centrifugation at $15000 \mathrm{~g}$ for $30 \mathrm{~min}$. The pellets were dissolved in the minimum volume of water and dialysed for $60 \mathrm{~h}$ at $4^{\circ}$ against several charges of distilled water. The dialysed proteins from $0-600 \mathrm{~g}\left(\mathrm{NH}_{4}\right)_{2} \mathrm{SO}_{4} / 1$ were pooled, lyophilized and stored at $-14^{\circ}$ until required. This fraction obtained contained almost $90 \%$ of the PI units of the original TCA extract and contained four iso-inhibitors which were present in the same proportion as those found in broad bean (Vicia faba L.) (BBPI-I-IV) by Warsy et al. (I974). In all respects, e.g. sensitivity to $\mathrm{pH}$ and temperature, the field bean PI were identical to the broad bean PI.

The PI activity was measured and defined according to Kunitz (I947). Under the conditions of the assay Kunitz defined I unit of antitrypsin activity (TIU) as the amount of inhibitor which depressed the trypsin [EC 3.4.4.4] or chymotrypsin [EC 3.4.4.5] activity by one trypsin or chymotrypsin unit. Specific activity of the inhibitor was defined as the number of trypsin-inhibitor units $/ \mathrm{mg}$ inhibitor protein. The specific activity of the $0-600 \mathrm{~g}\left(\mathrm{NH}_{4}\right)_{2} \mathbf{2}^{-}$ $\mathrm{SO}_{4} / 1$ fraction was found to contain $4 \mathrm{IO}^{\mathrm{O}} \times \mathrm{IO}^{-3} \mathrm{TIU}$ per $\mathrm{mg}$ PI protein.

Diets

All diets except those based on FBM contained casein at a level of $120 \mathrm{~g}$ protein $/ \mathrm{kg}$ diet (Table I). The basal diet was supplemented with PI either active or autoclaved (control) with corresponding reductions in the starch levels at levels $(\mathrm{g} / \mathrm{kg}$ ) of $\mathrm{I} \cdot 25$ (diet A), 2.5 (diet B), $5^{\circ}$ (diet C) and Io (diet D). A raw-FBM diet containing I $20 \mathrm{~g}$ protein $/ \mathrm{kg} \operatorname{diet}$ (nitrogen $\times$ 6.25) was also fed and compared with an autoclaved-FBM diet (Table 1). The PI and dehulled, defatted FBM were autoclaved at $121^{\circ}$ and $I \mathrm{~kg} / \mathrm{cm}^{2}$ for 45 and $\mathrm{I} 5 \mathrm{~min}$ respectively, since in preliminary experiments it had been found that the PI activity was completely destroyed in $45 \mathrm{~min}$ and $90 \%$ of the PI activity in the raw FBM was destroyed in 15 min without causing adverse effects to the nutritive quality of the protein. All diets were supplemented with $2.5 \mathrm{~g}$ DL-methionine $/ \mathrm{kg}$.

In all, eighteen rats were subjected to each treatment over three different periods of 7 , 14 and $21 \mathrm{~d}$. The effects of PI on body-weight gain, protein efficiency ratio (PER) and $\mathrm{N}$ digestibility were followed.

\section{Statistical analysis}

The results were subjected to analysis of variance and a significant result was based on a level of probability less than $5 \%(P<0.05) 7 \mathrm{I}$ df were used for the casein diets and $\mathrm{I} 7 \mathrm{df}$ for the FBM diets. 
Table I. Composition of the diets $(\mathrm{g} / \mathrm{kg})$

$\begin{array}{lcc}\text { Casein } & \begin{array}{c}\text { PI-supplemented } \\ \text { diets }\end{array} & \begin{array}{c}\text { Field-bean } \\ \text { meal diets }\end{array} \\ \begin{array}{l}\text { Raw or heated } \\ \text { field-bean (Vicia faba L.) meal* }\end{array} & \text { I4I } & - \\ \text { Arachis oil } & 50 & 531 \\ \text { Salt mixture } \dagger & 50 & 50 \\ \text { Vitamin mixture } † & 12 & 50 \\ \text { DL-methionine } & 2 \cdot 5 & \mathbf{1 2} \\ \text { Proteinase inhibitors } \ddagger & - & -2 \cdot 5 \\ \text { Dextrinized starch }+ \text { maize starch } & \text { To I kg } & \text { To I kg }\end{array}$

* The dehulled beans were supplied by Lord Rank Research Centre, High Wycombe. The beans contained (g/kg dry matter): crude protein (nitrogen $\times 6.25$ ) 230, crude fibre 92, ash 40 , diethyl ether-extracted fat 14 . $\dagger$ Composition as described by Payne \& Stewart (1972).

¥ See Table 2.

Table 2. Live-weight gain ( $\mathrm{g} / \mathrm{d}$ per $\mathrm{kg}$ initial weight) of rats fed on either casein diets containing active- and autoclaved-proteinase inhibitors (PI) or raw and autoclaved field-bean (Vicia faba $L$.) meal $(F B M)$

(Mean values with their standard errors for six rats)

\begin{tabular}{|c|c|c|c|c|c|c|}
\hline \multirow[b]{3}{*}{ Diet $\dagger$} & \multicolumn{6}{|c|}{ Period on diet (d) } \\
\hline & \multicolumn{2}{|c|}{7} & \multicolumn{2}{|c|}{ I 4} & \multicolumn{2}{|c|}{21} \\
\hline & Mean & SE & Mean & SE & Mean & SE \\
\hline $\begin{array}{l}\text { A } \\
\text { AA }\end{array}$ & $\begin{array}{l}56 \cdot 4 \\
56 \cdot 6\end{array}$ & $\begin{array}{l}1.7 \\
0.8\end{array}$ & $\begin{array}{l}60 \cdot 4 \\
53 \cdot 3\end{array}$ & $\begin{array}{l}6 \cdot 0 \\
5 \cdot 3\end{array}$ & $\begin{array}{l}67 \cdot 4 \\
57 \cdot 3\end{array}$ & $\begin{array}{l}4 \cdot 3 \\
I \cdot 5\end{array}$ \\
\hline $\begin{array}{l}\text { B } \\
\text { BA }\end{array}$ & $\begin{array}{l}57 \cdot 6 \\
73 \cdot 2\end{array}$ & $\begin{array}{l}5.4^{*} \\
5 \cdot 7\end{array}$ & $\begin{array}{l}55 \cdot 9 \\
76 \cdot 4\end{array}$ & $\begin{array}{l}5 \cdot 0^{*} \\
4 \cdot 2\end{array}$ & $\begin{array}{l}68 \cdot 7 \\
69 \cdot 1\end{array}$ & $\begin{array}{l}4 \cdot 0 \\
7 \cdot 3\end{array}$ \\
\hline $\begin{array}{l}\mathrm{C} \\
\mathrm{CA}\end{array}$ & $\begin{array}{l}54 \cdot 0 \\
75 \cdot 3\end{array}$ & $\begin{array}{l}3 \cdot I^{*} \\
1 \cdot 7\end{array}$ & $\begin{array}{l}59 \cdot 0 \\
78 \cdot 1\end{array}$ & $\begin{array}{l}4.5^{*} \\
0.2\end{array}$ & $\begin{array}{l}66 \cdot 9 \\
75 \cdot 6\end{array}$ & $\begin{array}{l}5 \cdot 8 \\
3 \cdot 2\end{array}$ \\
\hline $\begin{array}{l}\text { D } \\
\text { DA }\end{array}$ & $\begin{array}{l}5 \mathrm{I} \cdot 3 \\
78 \cdot 4\end{array}$ & $\begin{array}{l}\mathrm{I} \cdot 2^{*} \\
0 \cdot 2\end{array}$ & $\begin{array}{l}71 \cdot 2 \\
93 \cdot 2\end{array}$ & $\begin{array}{l}4 \cdot 5^{*} \\
4 \cdot 2\end{array}$ & $\begin{array}{l}64 \cdot 0 \\
73 \cdot 7\end{array}$ & $\begin{array}{l}2 \cdot 8 \\
1 \cdot 7\end{array}$ \\
\hline $\begin{array}{l}\text { Raw FBM } \\
\text { Autoclaved FBM }\end{array}$ & $\begin{array}{l}19 \cdot 4 \\
45 \cdot 2\end{array}$ & $\begin{array}{l}4 \cdot 6^{*} \\
4 \cdot 7\end{array}$ & $\begin{array}{l}42 \cdot 4 \\
59 \cdot 0\end{array}$ & $\begin{array}{l}4.0^{*} \\
6.0\end{array}$ & $\begin{array}{l}54 \cdot 8 \\
66 \cdot 7\end{array}$ & $\begin{array}{l}1 \cdot 2 \\
5.5\end{array}$ \\
\hline
\end{tabular}

* Significant difference from control value $(P<0.001)$.

$\dagger$ Contained ( $\mathrm{g}$ active PI $/ \mathrm{kg}$ ): A, I.25; B, 2.5; C, 5; D, I0. Control diets AA, BA, CA and DA contained autoclaved $\mathrm{PI}$ at same level as in diets A, B, C and D respectively.

\section{RESULTS}

\section{Live-weight gain}

Significant growth depression occurred in rats given diets B, C and D compared with the controls (Table 2). The growth depression of rats at 7, I4 and $2 \mathrm{I} \mathrm{d}$ were $2 \mathrm{I}, 27$ and I \% on diet $\mathrm{B} ; 28,24$ and $12 \%$ on diet $\mathrm{C}$; and 35,24 and $13 \%$ on diet D respectively. PI inclusion levels greater than $\mathrm{I} \cdot 25 \mathrm{~g} / \mathrm{kg}$ resulted in highly significant $(P<0.00 \mathrm{I})$ growth depression over a $\mathrm{I} 4 \mathrm{~d}$ period. After this time, however, growth rate improved at all dietary PI inclusion levels. The growth depression observed in the rats given diets containing raw FBM compared to that of autoclaved FBM was approximately $57 \%$ after $7 \mathrm{~d}$. With increasing period of feeding the diet, the extent of this depression decreased. 
Table 3. Food intake $(g)$ of rats fed on either casein diets containing active and autoclaved proteinase inhibitors (PI) or raw and autoclaved field-bean (Vicia faba $L$.) meal (FBM)

(Mean values with their standard errors for six rats)

\begin{tabular}{|c|c|c|c|c|c|c|}
\hline \multirow[b]{3}{*}{ Diet $\dagger$} & \multicolumn{6}{|c|}{ Period on diet (d) } \\
\hline & \multicolumn{2}{|c|}{7} & \multicolumn{2}{|c|}{14} & \multicolumn{2}{|c|}{21} \\
\hline & Mean & SE & Mean & $\mathbf{S E}$ & Mean & SE \\
\hline $\begin{array}{l}\text { A } \\
A A\end{array}$ & $\begin{array}{l}128 \\
\text { IOI }\end{array}$ & $\begin{array}{r}12 \\
2\end{array}$ & $\begin{array}{l}243 \\
259\end{array}$ & 3 & $\begin{array}{l}492 \\
46 \mathrm{I}\end{array}$ & $\begin{array}{l}\text { II } \\
19\end{array}$ \\
\hline B & I 56 & I & 308 & 3 & 536 & $4 I$ \\
\hline BA & I 39 & 2 & 355 & 39 & 563 & 31 \\
\hline $\mathrm{C}$ & 143 & 6 & 322 & 9 & 425 & $74^{*}$ \\
\hline $\mathrm{CA}$ & 144 & 4 & 361 & 20 & 575 & 16 \\
\hline D & I I I & 2 & 245 & 13 & 349 & $46^{*}$ \\
\hline DA & IIO & 3 & 295 & 10 & 469 & 8 \\
\hline Raw FBM & 89 & 7 & 235 & $16^{*}$ & 365 & $18^{*}$ \\
\hline Autoclaved FBM & 110 & 3 & 292 & IO & 466 & 8 \\
\hline
\end{tabular}

* Significant difference from control value $(P<0.001)$.

$\dagger$ Contained (g active PI/kg): A, I.25; B, 2.5; C, 5; D, IO. Control diets AA, BA, CA and DA contained autoclaved $P I$ at same level as in diets $A, B, C$ and $D$ respectively.

Table 4. Trypsin [EC 3.4.4.4]-inhibitor units $(T I U)^{*}$ intake by rats fed on proteinase inhibitor (PI)-supplemented casein diets or a raw field-bean (Vicia faba $L$.) meal (FBM) diet

(Mean values with their standard errors for six rats)

\begin{tabular}{|c|c|c|c|c|c|c|}
\hline & & & Period & (d) & & \\
\hline & & & & & & \\
\hline Diet $\dagger$ & $\begin{array}{c}\text { TIU } \\
\text { intake }\end{array}$ & SE & $\begin{array}{c}\text { TIU } \\
\text { intake }\end{array}$ & SE & $\begin{array}{c}\text { TIU } \\
\text { intake }\end{array}$ & SE \\
\hline $\mathbf{A}$ & $65 \cdot 6$ & $6 \cdot 2$ & 124.5 & $I \cdot 5$ & $252 \cdot 2$ & 5.6 \\
\hline B & $159^{\circ} 9$ & $I \cdot O$ & 315.7 & $3 \cdot I$ & $549 \cdot 4$ & $42 \cdot 0$ \\
\hline C & $293^{-2}$ & $12 \cdot 3$ & $660 \cdot 1$ & $18 \cdot 5$ & $871 \cdot 3$ & $151 \cdot 7$ \\
\hline $\mathrm{D}$ & $455 \cdot 1$ & $8 \cdot 2$ & 1004.5 & $53 \cdot 3$ & 1430.9 & I 88.6 \\
\hline Raw FBM & 32.5 & $2 \cdot 6$ & 86.7 & 5.9 & $134 \cdot 3$ & $6 \cdot 6$ \\
\hline
\end{tabular}

* One unit of antitrypsin activity (TIU) is the amount of inhibitor which depressed trypsin activity by one trypsin unit (Kunitz, 1947).

$\dagger$ Contained (g active PI $/ \mathrm{kg}$ ): A, I.25; B, $2 \cdot 5 ; \mathrm{C}, 5 ; \mathrm{D}, 10$. Control diets AA, BA, CA and DA contained autoclaved $P I$ at same level as in diets $A, B, C$ and $D$ respectively.

\section{Food intake}

Irrespective of dietary PI inclusion levels, the food intakes of rats given active and autoclaved-PI diets were not significantly different for the first $7 \mathrm{~d}$ (Table 3 ). During the next I $4 \mathrm{~d}$, however, the food intake of rats given the active-PI diets (C, D and raw FBM) were significantly lower than the controls. Consumption of all diets, however, increased with the period of feeding and this was reflected in the improved growth rate. When the food intake was calculated on the basis of TIU consumed by the rats (Table 4), it was shown that rats given raw FBM consumed less TIU than those given diet $\mathrm{A}$. 
Table 5. Protein efficiency ratio (PER) $\ddagger$ for rats on diets containing casein and either active or autoclaved proteinase inhibitors $(P I)$ and raw or autoclaved field-bean (Vicia faba $L$.) meal $(F B M)$

(Mean values with their standard errors for six rats)

\begin{tabular}{|c|c|c|c|c|c|c|}
\hline \multirow[b]{3}{*}{ Diet† } & \multicolumn{6}{|c|}{ Period on diet (d) } \\
\hline & \multicolumn{2}{|c|}{7} & \multicolumn{2}{|c|}{14} & \multicolumn{2}{|c|}{$2 I$} \\
\hline & Mean & SE & Mean & SE & Mean & SE \\
\hline $\begin{array}{l}\text { A } \\
\text { AA }\end{array}$ & $\begin{array}{l}I \cdot 91 \\
2 \cdot 35\end{array}$ & $\begin{array}{l}0.10^{*} \\
0.16\end{array}$ & $\begin{array}{l}1 \cdot 85 \\
I \cdot 83\end{array}$ & $\begin{array}{l}0.21 \\
0.33\end{array}$ & $\begin{array}{l}1 \cdot 81 \\
I \cdot 83\end{array}$ & $\begin{array}{l}0.06 \\
0.03\end{array}$ \\
\hline $\begin{array}{l}\text { B } \\
\text { BA }\end{array}$ & $\begin{array}{l}1 \cdot 38 \\
2 \cdot 06\end{array}$ & $\begin{array}{l}0.20^{*} \\
0.11\end{array}$ & $\begin{array}{l}1.65 \\
1.87\end{array}$ & $\begin{array}{l}0.13 \\
0.12\end{array}$ & $\begin{array}{l}I \cdot 77 \\
I \cdot 88\end{array}$ & $\begin{array}{l}0.08 \\
0.06\end{array}$ \\
\hline $\begin{array}{l}\mathrm{C} \\
\mathrm{CA}\end{array}$ & $\begin{array}{l}I \cdot 39 \\
2 \cdot 48\end{array}$ & $\begin{array}{l}0.09^{*} \\
0.03\end{array}$ & $\begin{array}{r}I \cdot 59 \\
I \cdot 9 I\end{array}$ & $\begin{array}{l}0 . I^{*} \\
0.1 \text { I }\end{array}$ & $\begin{array}{l}1 \cdot 80 \\
2 \cdot 20\end{array}$ & $\begin{array}{l}0.12^{*} \\
0.18\end{array}$ \\
\hline $\begin{array}{l}\mathrm{D} \\
\mathrm{DA}\end{array}$ & $\begin{array}{l}1 \cdot 48 \\
2 \cdot 62\end{array}$ & $\begin{array}{l}0.05^{*} \\
0.10\end{array}$ & $\begin{array}{l}I \cdot 50 \\
I \cdot 93\end{array}$ & $\begin{array}{l}0.01^{*} \\
0.05\end{array}$ & $\begin{array}{l}1.52 \\
1.86\end{array}$ & $\begin{array}{l}0.2 I^{*} \\
0.05\end{array}$ \\
\hline $\begin{array}{l}\text { Raw FBM } \\
\text { Autoclaved FBM }\end{array}$ & $\begin{array}{l}0.68 \\
1 \cdot 53\end{array}$ & $\begin{array}{l}0.13^{*} \\
0.08\end{array}$ & $\begin{array}{l}I \cdot I 2 \\
I \cdot 42\end{array}$ & $\begin{array}{l}0.01^{*} \\
0.05\end{array}$ & $\begin{array}{l}I \cdot 3 I \\
I \cdot 53\end{array}$ & $\begin{array}{l}0.05^{*} \\
0.09\end{array}$ \\
\hline
\end{tabular}

* Significant difference from control value $(P<0.001)$.

$\dagger$ Contained (g active PI $/ \mathrm{kg}$ ): A, I $25 ; \mathrm{B}, 2.50 ; \mathrm{C}, 5 ; \mathrm{D}$, 10 . Control diets AA, BA, CA and DA contained autoclaved PI at same level as in diets A, B, C and D respectively.

$\$$ Live-weight gain per unit protein consumed.

PER

PER is normally measured $28 \mathrm{~d}$ after the commencement of feeding a diet but in this study the first measurements were made after $7 \mathrm{~d}$ in order to give some insight of the efficiency of protein utilization in the early stages of feeding PI to rats. Rats given casein plus autoclaved PI had higher PER values than rats fed diets containing active PI at all inclusion levels (Table 5). The differences in PER were particularly marked at $7 \mathrm{~d}$. After $14 \mathrm{~d}$, the differences were smaller but still significant for the diets CA and DA. This suggests some adaptation to the diet with the period of feeding. PER values for the raw- and autoclaved-FBM diets were significantly different $(P<0.00 \mathrm{I})$ after the 7 and $14 \mathrm{~d}$ feeding period but after $2 \mathrm{I} \mathrm{d}$ there was a marked improvement. In general the protein in the casein diets was better utilized than that in the FBM diets particularly in the early stages of the trial ( $7 \mathrm{~d}$ ).

\section{$N$ digestibility}

The apparent $\mathrm{N}$ digestibility of active- and autoclaved-PI diets was similar for all levels of PI inclusion except with diet D. At this level of active PI after I4 and 2 I d, N digestibility was decreased (Table 6). There was no difference in digestibility between the raw and autoclaved FBM but these were lower than those for the casein diets.

\section{DISCUSSION}

Clear evidence was obtained that PI extracted from FBM are physiologically active when fed at high levels in a synthetic diet. Compared with rats given raw-FBM diet an approximate intake of five times more TIU was required to produce any significant growth depression by $7 \mathrm{~d}$ in a synthetic diet (Tables 2 and 4 ). PI levels twice that of the endogenous levels of PI in dehulled bean $(1.25 \mathrm{~g} / \mathrm{kg})$ were without effect when supplied in a casein diet (Table 2). This indicates that the PI alone could not be responsible for the deleterious effects observed when raw FBM is supplied to rats unless these act synergistically with other factors 
Table 6. Apparent nitrogen digestibility for rats of casein diets containing active and autoclaved proteinase inhibitors $(P I)$ or raw and autoclaved field-bean meal (FBM)

(Mean values with their standard errors for six rats)

\begin{tabular}{|c|c|c|c|c|c|c|}
\hline \multirow[b]{3}{*}{ Diet } & \multicolumn{6}{|c|}{ Period on diet (d) } \\
\hline & \multicolumn{2}{|c|}{7} & \multicolumn{2}{|c|}{14} & \multicolumn{2}{|c|}{2 I } \\
\hline & Mean & $\mathrm{SE}$ & Mean & SE & Mean & $\mathbf{S E}$ \\
\hline A & 0.9 I I & 0.006 & 0.905 & 0.007 & 0.905 & 0.002 \\
\hline AA & 0.916 & 0.005 & 0.910 & 0.004 & 0.910 & 0.012 \\
\hline B & 0.916 & 0.006 & 0.915 & 0.003 & 0.925 & 0.013 \\
\hline BA & 0.931 & 0.003 & 0.934 & 0.007 & 0.933 & 0.006 \\
\hline C & 0.925 & 0.009 & 0.919 & 0.006 & 0.928 & 0.004 \\
\hline $\mathrm{CA}$ & 0.932 & 0.002 & 0.930 & 0.005 & 0.946 & 0.003 \\
\hline $\mathrm{D}$ & 0.891 & 0.001 & 0.875 & $0.009^{*}$ & 0.851 & $0.010^{*}$ \\
\hline DA & 0.900 & 0.005 & 0.930 & 0.003 & 0.913 & 0.007 \\
\hline Raw FBM & 0.839 & 0.006 & 0.847 & 0.005 & 0.830 & 0.004 \\
\hline Autoclaved FBM & $0.83 I$ & 0.005 & 0.859 & 0.005 & 0.835 & 0.012 \\
\hline
\end{tabular}

* Significant differences from control value $(P<0.001)$.

$\uparrow$ Contained (g active PI $/ \mathrm{kg}$ ): A, I.25; B, 2.5; C, 5; D, I0. Control diets AA, BA, CA and DA contained autoclaved $P I$ at same level as in diets $A, B, C$ and $D$ respectively.

present in the raw meal. Any such factors might be eliminated during the extraction and purification of the PI.

These results are contrary to the findings of Kakade et al. (1973), who reported that approximately $40 \%$ of the growth-depressing effect obtained when soya-bean extract was fed to rats could be accounted for by the PI. The technique of Kakade et al. (1973), involved feeding rats crude soya-bean extract from which the PI had been selectively removed by affinity chromatography. Comparison was made with groups of rats fed on either an original extract or the heat-treated extract. The PI activity present in such extracts will have been more compared with similar extracts from FBM. Evidence that this is so, is provided by other workers who have shown FBM to contain between only $12 \%$ (Marquardt et al. 1975) and $20 \%$ (Wilson et al. $1972 a$ ) of the TIU of raw soya-bean meal.

In agreement with the work reported here, Wilson et al. $(1972 b)$ were also not able to show any growth depression when diets based on autoclaved FBM, containing PI in amounts equivalent to that in the raw FBM were fed to chicks. The beneficial effect of autoclaving FBM may be the result of a combination of interrelated factors. Food consumption of rats fed on raw-FBM diets was reduced initially, suggesting poor palatability compared with autoclaved-FBM diets. Factors other than palatability, however, must also be involved since the decrease in food consumption, though not large, was associated with a highly significant depression of growth $(57 \%)$ and PER (44\%) (Tables 2 and 5). Heat-susceptible anti-growth factors such as phytohaemagglutinins could be involved since autoclaved FBM in the diet of rats resulted in an improvement in the live-weight gain, food intake and PER. Aspects concerning anti-nutritional factors such as PI, phytohaemagglutinins, vicine, antienzymes and metal-binding factors in legumes have been reviewed by Liener (1969, 1977). The significance of such anti-nutritional factors has not been investigated completely in any one legume.

Apart from the beneficial effects of autoclaving on the destruction of anti-nutritional factors, autoclaving might also denature refractive proteins in the raw FBM and thereby 
increase the availability of the amino acids in these proteins to rats. Evidence has been provided by Fukushima (I968), that the native protein molecules of soya-bean meal are quite compact and less readily hydrolysed by proteinases than the denatured proteins. Since the major storage proteins of soya-bean meal and FBM have similar properties and composition (Derbyshire et al. 1976) they may also behave in a similar manner from a digestion viewpoint.

Although in this work apparent $\mathrm{N}$ digestibility was not affected, live-weight gain, food intake and PER were depressed in rats supplied with raw-FBM diets. This result is in agreement with the apparent $\mathrm{N}$ digestibility values reported for soya-bean extracts (Kakade et al. I973). N digestibility in rats fed on $10 \mathrm{~g} \mathrm{PI} / \mathrm{kg}$ was, however, significantly affected after I 4 d. Presumably, the PI formed resistant complexes with trypsin and chymotrypsin in the intestinal tract which remained undigested and were subsequently voided in faeces thus resulting in a significant loss of cysteine and methionine to the rats. Further aspects concerning the physiological effect of PI from FBM will be discussed in a subsequent paper.

It has been suggested that the physiological effect of PI is to stimulate the pancreas to produce excessive amounts of enzymes which are lost to the animal in the faeces. In this respect Barnes et al. (1965) and Barnes \& Kwong (1965) have pointed out that since trypsin is rich in cystine the endogenous loss of this enzyme may account for the cystine deficiency noted in animals fed on diets containing raw soya-bean meal or soya-bean trypsin inhibitor. With the demonstration that the PI from broad beans (Warsy et al. 1974) are rich in cystine, it also seems possible that a dietary loss of cystine by way of an enzyme-inhibitor complex could contribute to the growth depression of the rats fed on diets containing raw FBM. Evidence in support of this effect has also been presented by Khayambashi \& Lyman (1966) in investigations with rats to ascertain whether soya-bean trypsin inhibitor could induce growth depression when food intake and protein availability were not contributing factors. Their results revealed that the PI-fed animals had higher levels of intestinal proteases, TCAinsoluble $\mathrm{N}$ and seventeen times more cystine than similar materials from the controls (diets containing autoclaved soya-bean meal). They concluded that growth depression was due to a loss of the essential amino acids, methionine and valine, caused by the PI stimulating the pancreas to secrete excessive quantities of proteins including enzymes into the intestinal tract. Furthermore, it was also suggested that much of this endogenous $\mathrm{N}$ could be reabsorbed but as a result of bacterial degradation particularly of those amino acids most limiting for growth into amines, mercaptans and other nitrogenous products these would be of no nutritional value to the animal. Such mechanisms might explain the lack of a difference in apparent $\mathrm{N}$ digestibility between rats fed on raw- and autoclaved-FBM diets, the loss of these amino acids as urea- $\mathrm{N}$, however, was reflected in reduced growth and protein utilization.

Recently, Ward et al. (I977) have reported that more than $50 \%$ of the heat-labile growth inhibitor responsible for the poor utilization of field beans is located in the hull fraction of the bean. Since dehulled FBM was used in this study, other factors must be responsible for the poor growth-promoting qualities of raw FBM.

The mechanisms by which the growth depression is induced by feeding raw FBM are unknown and will probably remain controversial until all of the individual components in the raw FBM have been isolated and their biological effects, both individual and collective, have been established. The evidence presented in this study, however, regarding the response of rats to unnaturally high levels of PI indicate that the level of PI present in field bean are not significantly important to rats. 


\section{REFERENCES}

Barnes, R. H. \& Kwong, E. (1965). J. Nutr, 86, 245.

Barnes, R. H., Kwong, E. \& Fiala, G. (I965). J. Nutr. 85, 123.

Derbyshire, E., Wright, D. S. \& Boulter, D. (1976). Phytochemistry r5, 3.

Fukushima, D. (1968). Cereal Chem. 45, 203.

Gertler, A., Birk, Y. \& Bondi, A. (1967). J. Nutr. 91, 358.

Ishaaya, I. \& Birk, Y. (1965). J. Fd Sci. 30, I18.

Kadirvel, R. \& Clandinin, D. R. (I974). Poult. Sci. 53, 1810.

Kakade, M. L., Hoffa, D. E. \& Liener, I. E. (1973). J. Nutr. 103, 1772.

Khayambashi, H. \& Lyman, R. L. (I966). J. Nutr. 89, 455.

Kunitz, M. (1947). J. gen. Physiol. 30, 29 I.

Liener, I. E. (1951). J. biol. Chem. 193, I83.

Liener, I. E. (1969). Toxic Constituents of Plant Foodstuffs [I. E. Liener, editor]. New York: Academic Press.

Liener, I. E. (1977). In Protein Nutritional Quality of Foods and Feeds, part 2, p. 523 [M. Friedman, editor]. New York: Marcel Dekker Inc.

Marquardt, R. R. \& Campbell, L. D. (1973). Can. J. Anim. Sci. 53, 741.

Marquardt, R. R., McKirdy, J. A., Ward, T. \& Campbell, L. D. (I975). Can. J. Anim. Sci. 55, 42 I.

Nitsan, Z. (1971). J. Sci. Fd Agric. 22, 252.

Osborne, T. B. \& Mendel, L. B. (1917). J. biol. Chem. 32, 369.

Payne, P. R. \& Stewart, R. J. C. (1972). Lab. Anim. 6, 135.

Rackis, J. J. (I965). Fedn Proc. Fedn Am. Socs exp. Biol. 24, I488.

Sohonie, K., Apte, U. \& Ambe, K. S. (1958). J. Scient. ind. Res. ${ }_{7}$ C, 42.

Ward, T., Marguardt, R. \& Campbell, L. D. (1977). J. Nutr. 107, 1325.

Warsy, A. S., Norton, G. \& Stein, M. (1974). Phytochemistry 13, 2481.

Wilson, B. J. \& McNab, J. M. (1972). Br. Poult. Sci. 13, 67.

Wilson, B. J., McNab, J. M. \& Bentley, H. (1972a). J. Sci. Fd Agric. 23, 679.

Wilson, B. J., McNab, J. M. \& Bentley, H. (1972b). Poult. Sci. r3, 52 I. 